\title{
The origins of informality: the ILO at the limit of the concept of unemployment
}

\author{
Aaron Benanav \\ The University of Chicago, 5845 South Ellis Avenue, Gates-Blake Rm. 303, Chicago, IL 60637, USA. \\ *Corresponding author. E-mail: abenanav@uchicago.edu
}

\begin{abstract}
Official histories suggest that the International Labour Organization (ILO) adopted the term 'informal sector' as a replacement for 'traditional sector', which, in its pairing with the 'modern sector', had fallen out of favour. This article argues that the adoption of the informal sector concept is better understood as arising out of a different context: the ILO's post-war efforts to generate a globally operational concept of unemployment for use in the 'developing world'. ILO officials abandoned this project in the late 1960s when they realized that, where work for wages did not constitute a widespread social norm, an accurate measure of what they called 'disguised unemployment' was impossible to construct. That led the ILO to develop alternative constructs, including 'employment in the informal sector'. However, it proved difficult for the agency to operationalize those, too, and it soon found itself losing control of the policy implications of the measures that it was producing.
\end{abstract}

Keywords: development history; history of economic statistics; ILO; informal sector; unemployment

In 1944, the International Labour Organization (ILO) ratified its Declaration of Philadelphia, which enjoined the organization to support programmes aimed at creating and sustaining 'full employment' among 'all peoples everywhere'. 'To fulfil this mandate, the ILO set out to develop a globally operational concept of unemployment for use across the 'developing world'. ${ }^{2}$ In spite of the difficulties they encountered, ILO officials came to see such a statistical construction as the necessary foundation of any viable full employment policy. David Morse, Director-General of the ILO between 1948 and 1970, explained that, 'without some idea of the order of magnitude of the employment problems that countries face, it is impossible to determine what and how much to do, whether the situation is getting better or worse, and how policy measures are affecting it'. ${ }^{3}$ The situation in which the ILO found itself, with respect to this statistics-making project, was nevertheless paradoxical. Unemployment levels in less developed countries (LDCs) appeared to be rising rapidly, making the need for improved employment policies feel ever more urgent. However, at the same time, measuring unemployment levels came to seem like an increasingly hopeless task, since the concept of unemployment failed to describe the forms of labour insufficiency that were expanding rapidly across the 'developing world'.

\footnotetext{
1'The twenty-sixth session of the International Labour Conference', International Labour Review (henceforth ILR), 50, 1, 1944, pp. 38-9. On the ILO, see Anthony Alcock, History of the International Labour Organization, New York: Macmillan, 1971; Gerry Rodgers, et al., The ILO and the quest for social justice, 1919-2009, Ithaca, NY: ILR Press/Cornell University Press, 2009.

${ }^{2}$ ILO officials were interested in developing a concept of unemployment that could be operationalized throughout the world, hence a globally operational measure. The ILO did not produce a measure of global unemployment - that is, an aggregate statistic for the entire world labour force - until the 1990s. On the project of UN statistics making, see Michael Ward, Quantifying the world: UN ideas and statistics, Bloomington, IN: Indiana University Press, 2004.

${ }^{3}$ David Morse, 'Unemployment in developing countries', Political Science Quarterly, 85, 1, 1970, p. 4.

() Cambridge University Press 2019.
} 
As the ILO official Jacques Lemoine explained in a telegram to Rudolph Peterson, director of the Second Development Decade of the United Nations (UN), the problem that labour statisticians faced was that the concept of unemployment did not 'readily apply' in LDCs, rendering existing measures of unemployment 'largely meaningless'. This article examines the ILO's contributions to development economics, focusing on the organization's shifting approaches to the problem of measuring insufficient employment in LDCs between the 1950s and 2003. I argue that the recurrent problem that the ILO faced was that real divisions in lived experience between labour-force participation and non-participation, as well as between the employed and the unemployed - were lacking in economies where only a minority of economic life was organized by means of wage-labour. ${ }^{5}$ As populations shifted from rural to urban settings, many people continued to work on their own account, either for themselves or as unpaid family labour. They performed a range of economic activities while earning low incomes and therefore appeared to be caught in a liminal space between unemployment and full employment, which proved difficult to clarify via statistical construction, or to rectify via government action.

The ILO was particularly attuned to the statistical and political difficulties encountered in this regard because, unlike economists and other social scientists, the organization was interested neither in economic abstractions nor in rich empirical description, but rather in operational concepts that could be regularly reported by government agencies in a standard form. ${ }^{6}$ Under Morse's tenure, this international statistics-making project took on an urgent political character. Morse had transformed the ILO into a development agency with a particular social agenda: it was to guide LDCs along a path that would avoid the social catastrophes, and above all socialist revolutions, which had afflicted the West in the course of its industrialization. ${ }^{7}$ Rising levels of 'labour underutilization' in LDCs threatened this project by leading to 'widespread unrest'.

In the 1950s and 1960s, the ILO tried to standardize a concept of 'disguised unemployment', also called 'underemployment', as a way to account for the many individuals who found themselves neither unemployed nor fully employed in LDCs and to draw attention to the need for better employment policies. ${ }^{9}$ I argue that in the late 1960s and early 1970s, the ILO was forced to abandon this framework in the face of its apparent inoperability, even as the organization was calling for a greater global attention to issues of employment insufficiency in LDCs via its World Employment Programme (WEP), launched in 1969, and its World Employment Conference (WEC), held in 1976. That conference also introduced 'basic needs' as a new object of economic development. By the time that the conference met, the ILO had begun to adopt a new framework, focused on analysing 'employment in the informal sector'. ${ }^{10}$ That term went on to achieve a

${ }^{4}$ ILO Archive, Geneva (henceforth ILOA), file NYLO 1-2-2-6, jacket 2, telegram from ILO to UN, n.d.

${ }^{5} \mathrm{My}$ approach here draws from Mary S. Morgan, 'Seeking parts, looking for wholes', in Lorraine Daston and Elizabeth Lunbeck, eds., Histories of scientific observation, Chicago, IL: University of Chicago Press, 2011; and Daniel Spiech, 'The use of global abstractions: national income accounting in the period of imperial decline', Journal of Global History, 6, 1, 2011, pp. $7-28$.

${ }^{6}$ For a discussion of post-war efforts to extend the concept of unemployment to LDCs, see Gunnar Mydral, Asian drama: an inquiry into the poverty of nations, vol. 2, New York: Twentieth Century Fund, 1968, ch. 21.

${ }^{7}$ Daniel Maul, "Help them move the ILO way": the International Labor Organisation and the modernization discourse in the era of decolonization and the Cold War', Diplomatic History, 33, 3, 2009, pp. 387-404; see also Daniel Maul, Human rights, development and decolonisation: the International Labour Organization, 1940-70, Basingstoke: Palgrave Macmillan, 2012, pp. 121-51.

${ }^{8}$ Morse, 'Unemployment', p. 5.

${ }^{9}$ See, for example, ILO, Measurement of underemployment, Geneva: ILO, 1957.

${ }^{10}$ See Paul E. Bangasser, 'The ILO and the informal sector: an institutional history', Geneva: ILO, 2000. The first appearance of this term was in a lecture given by Keith Hart at the Institute for Development Studies in Sussex, in 1971, later published as Keith Hart, 'Informal income opportunities and urban employment in Ghana', Journal of Modern African Studies, 11, 1, 1973, pp. 61-89. Its first appearance in ILO literature was ILO, Employment, incomes and equality: a strategy for increasing productive employment in Kenya, Geneva: ILO, 1972 (henceforth Kenya report). 
much wider 'currency' within development discourses in the 1980s and 1990s, although the meaning or implications of informality remained ambiguous and were widely contested. ${ }^{11}$

This article locates the ILO's promotion of the informal sector concept within the crisis of its previously prevailing framework around disguised unemployment. Efforts to standardize the former concept encountered many of the same problems as the latter. In analysing the informality concept as part of a larger history of unemployment, this article also extends the approach of European and North American historians of unemployment into global history. ${ }^{12}$ Those historians emphasized the surprisingly late origins of this term, as well as its inherent fragility. In the second half of the twentieth century, large parts of the populations of Asia, Africa, and the Americas fell victim to that fragility, as they came to depend on finding work in monetary economies in spite of a persistently low demand for their labour. On the fiftieth anniversary of the adoption of the Declaration of Philadelphia, the former director of the WEP Louis Emmerij lamented that 'the employment problem has become universal, and in some places has disastrous proportions'. ${ }^{13}$ Yet, even at that time, ILO statisticians remained at a loss in figuring out whether and how to include a variety of proliferating employment conditions, such as precarious subcontracted labour and insecure on-call employment, within its broader measures of employment insufficiency. ${ }^{14}$

Precisely because the objective matter with which ILO officials were working was itself indistinct or underdetermined, it was exploitable by agents with different perspectives. ${ }^{15}$ ILO officials tried to shape reality through their statistics-making project, but they lost control of this process in the 1970s and 1980s, when a crisis of development planning allowed for the rise of new, neoliberal perspectives on international economic development. ${ }^{16}$ Statistical categories like informality were seized upon by those waiting in the wings, with their own ideas to sell, in the course of an era that saw the ILO fall from an increasingly influential position to one of growing marginality. This is a story about international institutions as active agents. ${ }^{17}$ But it is also about their lack or loss of agency, owing to the resistance of indeterminate realities and the play of political forces.

\section{Exporting 'unemployment' to the 'developing world'}

The main concept used to analyse issues of employment insufficiency in LDCs in the 1950s and 1960s was 'disguised unemployment', also called 'underemployment'. This paradoxical concept described individuals who had worked their entire lives, typically in agriculture or urban handicrafts, as in some sense unemployed. In describing low-productivity work as a type of

\footnotetext{
${ }^{11}$ Lisa Peattie, 'An idea in good currency and how it grew: the informal sector', World Development, 15, 7, 1987, pp. 851-60.

${ }^{12}$ See John A. Garraty, Unemployment in history: economic thought and public policy, New York: Harper \& Row, 1978; Alexander Keyssar, Out of work: the first century of unemployment in Massachusetts, Cambridge: Cambridge University Press, 1986; Robert Salais, Nicolas Baverez, and Bénédicte Reynaud, L'invention du chômage, Paris: Puf, 1986; Christian Topalov, Naissance du chômeur, 1880-1910, Paris: Albin Michel, 1994; William Walters, Unemployment and government: genealogies of the social, Cambridge: Cambridge University Press, 2000.

${ }^{13}$ Louis Emmerij, 'The employment problem and the international economy', ILR, 133, 4, 1994, p. 460.

${ }^{14}$ ILO, Statistics of employment in the informal sector, Geneva: ILO, 1993, pp. 13-14.

${ }^{15}$ On the politics of statistics-making, see Alain Desrosières, La politique des grands nombres: histoire de la raison statistique, Paris: La Découverte, 1993; Timothy Mitchell, 'Fixing the economy', Cultural Studies, 12, 1, 1998, pp. 82-101; Adam Tooze, Statistics and the German state 1900-1945: the making of modern economic knowledge, Cambridge: Cambridge University Press, 2001.

${ }^{16}$ On the neoliberal turn in development policy, see John Toye, Dilemmas of development: reflections on the counterrevolution in development economics, Oxford: Basil Blackwell, 1987; Dieter Plehwe, 'The origins of neoliberal economic development discourse', in Philip Mirowski and Dieter Plehwe, eds., The road from Mont Pèlerin: the making of the neoliberal thought collective, Cambridge, MA: Harvard University Press, 2009.

${ }^{17}$ See Sandrine Kott, 'International organizations: a field of research for a global history', Studies in Contemporary History, 8, 2011, pp. 446-50.
} 
unemployment, which was to be overcome in the course of economic development by means of the creation of new jobs, developmental economists hoped to extend the reach of Keynesian analysis and policy prescriptions from the highly developed countries to the less developed world. As decolonization unfolded, more and more independent states took up the notion of disguised unemployment for themselves, deploying the term in employment surveys and in projections of future trends. Government agencies frequently requested ILO assistance in these efforts.

Given this context, it is surprising to learn that the term 'disguised unemployment' was originally developed not for application in LDCs but rather for use in Europe and the US. Telling the story of those origins helps clarify the nature of the problems that ILO officials later encountered in measuring disguised unemployment around the globe. The first person to use the term was the British economist Joan Robinson. She developed the concept in 1936, in an effort to make Keynes's theory more applicable to real-world examples. ${ }^{18}$ Ever since Charles Booth had examined the problem of the unemployed in 1889, it had been known that many people designated as unemployed were actually 'irregularly employed': they worked at least some of the time. ${ }^{19}$ Keynes had ignored these real-life ambiguities in the General theory: he defined involuntary unemployment as enforced idleness, rather than as a frantic search for work. ${ }^{20}$

Robinson pointed out that, in reality, many of the unemployed did not remain idle: they worked in whatever ways they could, living 'hand-to-mouth'. ${ }^{21}$ She gave the example of workers who once held high-productivity jobs in auto plants but were now working in jobs with much lower productivity, selling matches on street corners. ${ }^{22}$ Robinson argued that these matchbook salesmen could still be described as unemployed within the technical terms of a Keynesian analysis, although their unemployment took a disguised form. When rates of unemployment were low, a government stimulation of demand could still constitute an effective intervention, if it induced disguised unemployment to become visible and then to resolve itself into new employment: workers would reallocate themselves from low-productivity activities on street corners back to high-productivity activities in factories without causing inflation. ${ }^{23}$

Economists began to adapt Robinson's concept for use in what were then called 'backwards areas' during the Second World War, in the context of wartime planning and preparations for post-war reconstruction. Paul Rosenstein-Rodan, who originated the theory of 'big-push' industrialization, was one of the first economists to use the term 'disguised unemployment' to refer to a specific form of employment insufficiency in LDCs, in an article on international development published in $1944 .^{24}$ The difficulty involved in this conceptual move was that, unlike in the UK in 1936, individuals selling matches on street corners in Cuba or Indonesia were unlikely to have ever held high-productivity jobs in factories. ${ }^{25}$ What was the reference by comparison to which their productivity could be described as low and their labour as a form of

\footnotetext{
${ }^{18}$ Joan Robinson, 'Disguised unemployment', Economics Journal, 46, 182, 1936, pp. 225-37.

${ }^{19}$ Charles Booth, Life and labour of the people of London, 3rd edition, London: Williams and Norgate, 1892, p. 150.

${ }^{20}$ J. M. Keynes, The general theory of employment, interest, and money, New York: Harcourt, 1964 (first published 1936), p. 15.

${ }^{21}$ Robinson, 'Disguised unemployment', p. 227.

${ }^{22}$ Ibid., pp. 229-30.

${ }^{23}$ Ibid., pp. 227-28.

${ }^{24}$ Paul Rosenstein-Rodan, 'The international development of economically backward areas', International Affairs, 20, 2, 1944, pp. 157-65. Josef Steindl appears to have been the first economist to apply the term 'disguised unemployment' to LDCs, at least in the English language. In 1942, he used the term in the course of describing economic issues associated with the expansion of wartime production in British India. See Josef Steindl, 'The impact of the war in India,' Bulletin of the Oxford University Institute of Economics and Statistics, 4, 5, 1942, p. 107. See also Kurt Mandelbaum, The industrialisation of backward areas, Oxford: Basil Blackwell, 1947.

${ }^{25} \mathrm{Cuba}$ and Indonesia were both countries where studies of disguised unemployment were carried out in the early postwar period. For a list of countries carrying out such studies, see ILO, Measurement of underemployment: concepts and methods, Geneva: ILO, 1966.
} 
unemployment? This question would haunt the enterprise of compiling labour-force statistics in the years that followed.

Rosenstein-Rodan decided to define disguised unemployment in LDCs in absolute terms, as a measure of workers with 'zero marginal-productivity': these workers could leave their current occupations without causing any fall in levels of production. ${ }^{26}$ It was as if they contributed nothing; mere hangers-on, they were retained on peasant farms because of familial obligations rather than economic rationality. ${ }^{27}$ Were a big push to jumpstart the process of industrialization, Rosenstein-Rodan argued, these agrarian workers would end up forming the core of the industrial proletariat. This perspective was systematized in the $1950 \mathrm{UN}$ report on economic development, largely written by the Caribbean economist Arthur Lewis, who went on to found the field of development economics. ${ }^{28}$ For Lewis and his colleagues, the only way to resolve disguised unemployment was 'rapid economic development' by way of economic growth. ${ }^{29}$

In their work on these issues, ILO officials drew on the analyses of economists like Lewis, but also diverged from his approach in significant ways. In the 1950s and 1960s, Lewis was drawn into a debate with more orthodox economists, who argued that his concept of surplus labour in agriculture was inconsistent. ${ }^{30}$ Lewis went on to win the Nobel Prize in economics, but he was forced to share the prize with Theodore Schultz, who was his main critic. The ILO sidestepped such theoretical disputes by taking a more practical approach. ILO statisticians focused on developing an operational definition of disguised unemployment for use in government planning. Attempts to measure zero-marginal-productivity workers in agriculture had proven unworkable: experimental farms were set up in India, but their findings proved difficult to generalize. ${ }^{31}$ The ILO therefore began to look for an alternative methodology as early as the 1950s. Here, the ILO's goals were inflected by its particular approach to international economic development.

\section{Efforts to standardize 'underemployment' in the 1950s}

In 1948, the American David Morse replaced Edward Phelan as Director-General of the ILO. Morse was a major supporter of Truman's Point IV Declaration, which sought to develop what were now called 'underdeveloped areas' as part of the US's Cold War strategy. ${ }^{32}$ Morse oversaw the partial reorganization of the ILO in the service of that strategy, as a technical assistance agency providing workforce planning to newly independent states. ${ }^{33}$ ILO employees also intervened in wider debates around international economic development in numerous venues, including at the annual International Labour Conference (ILC) and at the quinquennial International Conference of Labour Statisticians (ICLS), as well as in the ILO's in-house journal, the International Labour Review. In all of these venues, the ILO pushed for a greater attention to social objectives in development, 'so that', as Morse explained, 'the experience of this great organization may be made immediately and practically available for the solution of the many problems with which social and economic pioneers are normally confronted'. ${ }^{34}$

\footnotetext{
${ }^{26}$ Rosenstein-Rodan, 'International development', p. 160.

${ }^{27}$ Ibid.

${ }^{28} \mathrm{UN}$, Measures for the economic development of under-developed countries, New York: UN, 1951; W. Arthur Lewis, 'Economic development with unlimited supplies of labour', Manchester School, 22, 2, 1954, pp. 139-91.

${ }^{29} \mathrm{UN}$, Measures, p. 7.

${ }^{30}$ See Robert Tignor, 'Unlimited supplies of labour', Manchester School, 72, 6, 2004, pp. 702-4.

${ }^{31} \mathrm{ILO}$, 'Concepts and methods of the measurement of underemployment', meeting of experts on the measurement of underemployment, working paper 1, Geneva: ILO, 1963, p. 11.

${ }^{32}$ Maul, 'Help them move', p. 391.

${ }^{33}$ Rodgers, et al., ILO, pp. 180-5.

${ }^{34}$ ILO, Report of the director-general, Geneva: ILO, 1949, p. 3.
} 
The ILO took its turn towards developmentalism just as the term 'disguised unemployment' was beginning to come into wider use. In response to a 1949 UN survey of full-employment policies, officials from Burma, which had just achieved independence, already referred to 'disguised unemployment' as the main problem that they faced. ${ }^{35}$ This term went on to be used by many government planners, whatever the extent of their agreement with Western economists about the correct path to development. The ILO's first contribution to standardizing the definition of disguised unemployment came in 1951. At a meeting of the ILO's Asian Advisory Committee on the topic of 'underemployment in Asia: its causes and remedies', the ILO official Chiang Hsieh defined underemployment, which soon became a more common term for disguised unemployment, in a new way: as the difference between the labour force's actual and potential working time. ${ }^{36} \mathrm{He}$ also described multiple forms of underemployment, including a 'disguised' form, consisting of workers whose underemployment was difficult to measure, since they appeared to be fully employed but were actually working with low levels of productivity. ${ }^{37}$

Drawing on Hsieh's approach, the ILO produced a document describing best practices for measuring underemployment for the 1957 ICLS, held in Geneva at the ILO headquarters. ${ }^{38}$ In its preparatory report, the ILO defined underemployment in Keynesian terms as 'the difference between the actual employment and the theoretical full employment of the labour force'. ${ }^{39}$ The question remained, however: how could this difference be observed? In what sense was full employment an aspect of the world that could be measured by its absence?

ILO officials first tried to generate an 'objective' measure of underemployment. ${ }^{40}$ The gold standard of such objectivity was found in contemporary approaches to unemployment (which, it should be noted, had only been standardized ten years earlier, in 1947). ${ }^{41}$ To designate individuals as unemployed, surveyors asked them about the concrete steps that they had taken to look for work. Whether someone was described as wanting work was left to the judgement neither of the interviewer nor of the interviewee: it was a matter of objectively recording job-search activity, rather than evaluating subjective intentions. In LDCs, it turned out to be impossible to apply a similar standard for underemployment. Most people did not engage in job-search activities. There were few jobs on offer, so most people survived by making work for themselves.

The ILO therefore examined alternative approaches, based on surveys of underemployment carried out in Italy, Japan, Puerto Rico, and the Philippines. ${ }^{42}$ In the Philippines, surveyors simply asked workers for their subjective judgements: did they want more work? The problem was that, in many cities, even wage-workers who worked full time tended to answer this question affirmatively: many people earned such low wages that they wanted to work more than 40 hours a week. ${ }^{43}$ Meanwhile, in the countryside, interviewers were forced to record many answers to the same question as 'confused'. ${ }^{44}$ Rural-dwellers may not have accepted their poverty as fate, but few dreamed of overcoming that poverty by becoming factory workers. They had not yet taken on the government's employment norm as their own. Given these difficulties, an alternative approach was adopted in Puerto Rico: statisticians relied on their own judgements, simply

\footnotetext{
${ }^{35} \mathrm{UN}$, Maintenance of full employment, Lake Success, NY: UN, 1949, p. 89.

${ }^{36}$ Chiang Hsieh, 'Underemployment in Asia, I: nature and extent', ILR, 65, 5, 1952, p. 704.

${ }^{37}$ Ibid., pp. 704, 709-10.

${ }^{38}$ ILO, The ninth International Conference of Labour Statisticians, Geneva: ILO, 1957, pp. 34-41.

${ }^{39}$ ILO, Measurement of underemployment (1957), p. 15.

${ }^{40}$ ILO, 'Concepts', p. 9.

${ }^{41}$ Ibid., pp. 35-6, 47, 71. See also ILO, The sixth International Conference of Labour Statisticians, Geneva: ILO, 1948.

${ }^{42}$ ILO, Measurement of underemployment (1957), pp. 9-10, 12-13; ILO, 'Concepts', pp. 30-3. Between 1952 and 1956 , Italian and Japanese economists developed concepts of latent unemployment, underemployment, and insufficient employment for use in labour-force surveys, at a time when their own rapidly growing economies were still significantly agricultural and crafts-based. The ILO focused on Filipino and Puerto Rican studies, as more broadly relevant to LDCs.

${ }^{43} \mathrm{ILO}$, 'Concepts', p. 14.

${ }^{44} \mathrm{ILO}$, Measurement of underemployment (1957), p. 22.
} 
deciding, for example, that all small farmers were underemployed. ${ }^{45}$ This approach discounted the agency of individuals in ways that made ILO statisticians uncomfortable. ${ }^{46}$ Even in countries where full employment had been achieved, not everyone of working age wanted to work full time. In spite of these misgivings, the ILO recommended that the consortium of statisticians agree on some standard of measurement, for use across developing countries. ${ }^{47}$

Economists and government planners who came together at the 1957 ICLS did not accept the ILO's recommendations. ${ }^{48}$ They agreed to standardize only the measure of visible forms of underemployment, that is, part-time workers who wanted full-time work. However, statisticians could come to no agreement with regard to what they called invisible forms of underemployment, that is, full-time workers designated as underemployed by reference to low levels of incomes earned, or low levels of productivity achieved. They postponed standardization to a later date.

The ICLS's failure to find a common approach in this case was no minor matter, for invisible underemployment was widespread. Especially in regions where 'non-monetary' economies were extensive, many workers were not paid by the hour and hence had no reason to economize on the use of their time. ${ }^{49}$ As a result, these workers tended to 'spread' their work in two directions: first, they shared their work out among members of their households; second, they allowed what work they had to fill their days. ${ }^{50}$ Such workers appeared to work full time but made extremely low incomes. Their disguised unemployment was thus itself disguised.

\section{Launching the World Employment Programme}

In the late 1950s and throughout the 1960s, technical debates about labour-force statistics began to take on a greater political urgency. More countries were taking up the task of development planning, but such planning was running into problems around planners' limited expertise, dispersed rural economies, and the devastations wrought by colonialism and wars of independence, to say nothing of the manoeuvrings of Cold War superpowers. As early as 1956, an ILO report noted that impediments to full employment in LDCs were proving 'by no means easy to overcome'. ${ }^{51}$ Particularly worrisome was India, which ended up with more unemployment at the end of its First Five Year Plan period than at the beginning. ${ }^{52}$ To look more deeply into the reasons why such plans were not succeeding, the ILO commissioned an expert report headed by the Brazilian economist Roberto de Oliveira Campos. ${ }^{53}$ This report laid out the contours of an analysis that the ILO would go on to develop over the course of the 1960s.

In this period, the ILO did not concern itself with failures to achieve economic growth, since this was an era of rapid growth in many developing countries. For that reason, its officials did not pay much attention to impediments to international trade, such as falling prices for agricultural exports or barriers to importing manufactures into the US and Europe, which soon became the focus of UNCTAD and the basis of proposals for a New International Economic Order (NIEO). Instead, the ILO focused on the apparent disconnect between rapid economic growth and actual employment expansion. ILO officials came to think of that disconnect as having two major sources. The first was rapid population expansion, which 'offset much of the decrease in

\footnotetext{
${ }^{45}$ Ibid., p. 22.

${ }^{46} \mathrm{Ibid}$., p. 16. In 1961, an official ILO recommendation stated that employment must be 'freely chosen', in additional to 'full' and 'productive'. See ILO, 'Concepts', p. 11.

${ }^{47}$ See ILO, Measurement of underemployment (1957), pp. 83-4, and 'draft resolution' included on pp. 85-7.

${ }^{48} \mathrm{ILO}$, The ninth International Conference of Labour Statisticians, Geneva: ILO, 1957, pp. 34-5.

${ }^{49} \mathrm{ILO}$, Measurement of underemployment (1957), pp. 66-7.

${ }^{50}$ ILO, 'Concepts', pp. 15, 37.

${ }^{51}$ ILO, 'Employment and unemployment: government policies since 1950, II', ILR, 74, 2, 1956, p. 129.

${ }^{52}$ See Ragnar Nurske, 'Reflections on India's development plan', Quarterly Journal of Economics, 71, 2, 1957, pp. $188-204$.

${ }^{53} \mathrm{ILO}$, Employment objectives in economic development, Geneva: ILO, 1961.
} 
unemployment that would otherwise arise as new jobs were created'. ${ }^{54}$ Population growth was an issue, not only in rural areas but also in urban ones: urban-dwellers were observed to be crowding 'into a small number of occupations, such as domestic service and petty trading' ${ }^{55}$ Yet, the 1961 report went on to argue that rising underemployment in LDC cities was a problem not only of a rapidly growing labour supply but also of a slowly rising labour demand.

That was the second source of the disconnect between economic growth and employment growth: many factories had been built in the LDCs, but those same countries saw little to no increase in manufacturing employment shares. The ILO argued that this failure had two causes. The first was a skewed 'composition of output'. ${ }^{56}$ Most of the demand for industrial goods in LDCs came from the rich, since the poor remained largely outside the monetary economy. That was a problem because rich people purchased goods that tended to be capital-intensive, such as cars and whisky, rather than labour-intensive, such as clothes and shoes. The second problem was that government policies generated absurd incentives with regard to the choice of techniques' ${ }^{57}$ Economic development strategies focusing on heavy industrial production encouraged firms in LDCs to spend scarce foreign exchange on the importation of labour-saving machinery, in spite of high or rising levels of urban underemployment.

The ILO feared that, in focusing on big-push industrialization, countries were not paying enough attention to social issues, which could prove explosive if left unchecked. ILO officials decided to sound the alarm: breaking with orthodoxy, they began to argue that encouraging economic growth was not enough, in itself, to ensure steady progress towards full employment in the 'developing world'. In 1964, the ILC adopted an official recommendation, no. 122, that governments develop employment policies with aims that are 'clearly and publicly defined, wherever possible in the form of quantitative targets' ${ }^{58}$ For such policies to be effective, it would be useful to know how much unemployment there was at any one time, so that governments could figure out whether the measures they took to control it were successful. The ILO therefore redoubled its efforts to develop an operational measure of unemployment for LDCs.

However, the agency's increasingly urgently felt political necessity came up against a practical impossibility. In 1963, the ILO had brought together officials from Morocco, the Philippines, Italy, Chile, Egypt, Japan, and India to produce recommendations for measuring underemployment in LDCs, including disguised or invisible forms of underemployment. ${ }^{59}$ By the time that the ICLS met again to consider the question of underemployment in 1966, many more countries had carried out surveys of underemployment using a variety of techniques, and often with ILO assistance. Yet statisticians at the 1966 conference were still unable to find common ground. They decided that the concept of invisible underemployment should be abandoned as unworkable. $^{60}$

The year that the ICLS made that decision was also the year that the ILO began building from its 1964 employment recommendation towards its 1969 WEP, which would become the agency's largest-scale intervention around development issues. It was also the year of the Ottawa Plan, which set a regional employment target for the Americas. ${ }^{61}$ Similar regional commissions were set up in Asia and Africa in 1968 and 1969. Also in 1969, on the fiftieth anniversary of the ILO's founding, Director-General David Morse officially launched the WEP. ${ }^{62}$ In his opening address,

\footnotetext{
${ }^{54}$ ILO, 'Employment and unemployment', p. 129.

${ }^{55} \mathrm{ILO}$, Employment objectives, p. 22.

${ }^{56}$ Ibid., pp. 63-6.

${ }^{57}$ Ibid., pp. 66-71.

${ }^{58}$ International Labour Conference, Record of proceedings of the 48th Session, Geneva, ILO: 1964, p. 780.

${ }^{59}$ ILO, 'Concepts'.

${ }^{60}$ See ILO, Measurement of underemployment (1966), pp. 77-80, and 'draft resolution' included on pp. 89-93. See also ILO, The eleventh International Conference of Labour Statisticians, Geneva: ILO, 1967, pp. 24-5.

${ }^{61}$ Rodgers, et al., ILO, p. 185.

${ }^{62}$ Ibid., pp. 186-94.
} 
Morse made a plea for greater attention to social objectives in development. ${ }^{63} \mathrm{He}$ argued that governments needed to reduce unemployment directly, through rural development, public works projects, and a reduction in the capital intensity of growth. ${ }^{64}$ The WEP was going to help countries figure out the best way to achieve these goals.

In calling for a greater focus on employment issues, the ILO added its voice to a growing chorus of critics. At this time, problems encountered in Indian economic planning remained at the centre of many economists' concerns. The Swedish economist Gunnar Myrdal published his three-volume opus, Asian drama, in 1968. In that same year, the Institute for Development Studies (IDS) in Sussex published its own volume, entitled The crisis in Indian planning. ${ }^{65}$ At the time, the IDS was headed by Dudley Seers, who would go on to play a major role in ILO research. Seers gave his famous 'Meaning of development' speech in 1969, in which he questioned the link between GNP growth and actual development. ${ }^{66}$ In the same year, in a speech given for the twenty-fifth anniversary of the Declaration of Philadelphia, Hans Singer, who was a former UN official and now an IDS economist helping the ILO to conceptualize the WEP, discussed this same issue: 'even a high rate of growth ... in terms of the Keynesian concepts of national income, savings, investment, etc.' had not precluded 'rising levels of unemployment'. ${ }^{67}$ All of these interventions focused on the failure of employment levels to rise in line with economic growth.

In using its institutional resources to emphasize this problem, and also to try to solve it, the ILO began to move from the margins of the UN development apparatus to its centre. In 1969, the agency won the Nobel Peace Prize for its role in promoting social security in the West over the fifty years of its existence. In his acceptance speech, Morse discussed the need for similar objectives in LDCs: 'it is of the utmost urgency that a way be found of making economic development a meaningful term for the dispossessed masses before it is too late' ${ }^{68}$ Morse repeatedly used this moment in the spotlight to echo the positions of IDS economists. At Columbia University in the same year, he argued that 'job creation and other social benefits' had to be 'accepted as of equal importance with the growth of production', as an emergency measure aimed at supporting 'order and stability' in LDCs. ${ }^{69}$ Then, at a conference held at Cambridge University in 1970, he famously and provocatively called for 'the dethronement of GNP' as the main statistical measure orienting economic policy. ${ }^{70}$ At this time, the ILO's views on employment promotion were taken up in plans for a second UN Development Decade. Even the World Bank, under the stewardship of Robert McNamara, began to look to the ILO for inspiration. $^{71}$

${ }^{63} \mathrm{ILO}$, Report of the Director-General: the World Employment Programme, Geneva: ILO, 1969, pp. 1-13.

${ }^{64}$ Ibid., p. 65.

${ }^{65}$ Paul Streeten and Michael Lipton, eds., The crisis of Indian planning, London: Oxford University Press, 1968.

${ }^{66}$ Dudley Seers, 'The meaning of development,' Revista Brasileira de Economia, 24, 3, 1970, pp. 5-28.

${ }^{67}$ ILOA, file WEP-3, jacket 1, Hans Singer, 'First thoughts: objectives of the World Employment Programme', 20 January 1969. See also ILOA, file WEP-3, jacket 2, Hans Singer, 'Speech on employment problems in developing countries and action programme for the decades of the 1970s', 8 May 1969.

${ }^{68}$ David Morse, ILO and the social infrastructure of peace, Nobel Prize speech, Oslo, 11 December 1969.

${ }^{69}$ David Morse, 'Employment and economic growth: an international perspective', Relations industrielles, 24, 4, 1969, p. 664.

${ }^{70}$ David Morse, 'The employment problem in developing countries', in Ronald Robinson and Peter Johnson, eds., Prospects for employment opportunities in the nineteen seventies, London: Cambridge University Press, 1971, p. 7. Archibald Callaway notes that 'the phrase "dethronement of GNP" became a recurring' and, in his view, also a 'distracting theme' at the conference. Archibald Callaway, 'The Cambridge conference on development: prospects for employment opportunities in the 1970s', Manpower and Unemployment Research in Africa, 4, 2, 1971, p. 4.

${ }^{71}$ Devesh Kapur, John P. Lewis, and Richard C. Webb, The World Bank: its first half century, vol. 1, Washington, DC: Brookings Institution Press, 1997, p. 255; H. W. Arndt, Economic development: the history of an idea, Chicago, IL: University of Chicago Press, 1987, pp. 97-100. 


\section{The demise of the 'underemployment' framework}

The late 1960s were a triumphant period for the ILO on the world stage but, behind the scenes, a conceptual crisis was brewing. Building on the 1964 employment recommendation, Morse had said that one of the main goals of the WEP would be to persuade countries to supplement GNP targeting with direct employment targeting. The problem that the ILO faced was that, in order to incorporate employment targeting into development plans, there had to be a reliable way to measure unemployment in LDCs, so that countries could meaningfully track their progress. ${ }^{72}$ All of the ILO's efforts to produce such a measure had failed. As the crisis of employment insufficiency in the 'developing world' worsened, ILO economists lost faith in the very measures that they had promoted, even as they now demanded that those measures be given greater attention.

Facing up to this statistical denouement, the ILO head office underwent a dramatic shift in perspective. Previously, ILO officials had seen the problem of measuring underemployment in LDCs as one of applying statistical categories under less than ideal conditions: they were simply trying to operationalize some sort of measure for widespread use. They now abandoned this project as unfeasible. ${ }^{73}$ In 1969 , the ILO economic adviser N. N. Franklin formed a 'working party' to discuss the 'pitfalls' encountered in conceptualizing data requirements for the WEP. ${ }^{74}$ The members of the working party explained their new thinking as follows. Statistical concepts used in employment targeting needed to be applicable across a wide variety of countries. However, if those concepts were to be applicable at all, social life had to be organized already in a way that was receptive to those concepts. In the industrialized countries, the generalization of wage relations had reorganized economic activity in a way that made it receptive to statistical measurement: thus, 'a wage-earning job is a relatively precise concept' based on a 'contract of employment, written or unwritten', with wages 'paid and received' and records 'kept ${ }^{\text {. }}$. The social conditions that 'make the concept' of such a job 'a relatively unambiguous one also facilitate its measurement'. ${ }^{76}$

In LDCs, most work was not organized via a wage relation. Instead, most people worked for themselves or as unpaid family contributors. The working party noted that, particularly in rural areas, where most of the population lived, 'it is doubtful whether the labour force', the most basic concept of labour statistics, 'is a meaningful or measurable entity', since 'men, women and children all contribute to productive activities' without distinguishing between economic and non-economic ones. ${ }^{77}$ Similar issues also arose in cities. Urban workers were more deeply imbricated in monetary economies but mostly continued to work for themselves or for family members. Given these conditions, many workers felt little need to economize on the time they spent working. Insofar as family members were not paid, there was no need to distinguish between those who worked and those who did not. ${ }^{78}$ Instead, work was spread throughout a given household and over the course of a given day.

For these reasons, and across much of the world, it was proving impossible to measure the size of the labour force, its current productivity, or its potential productivity at full employment. These categories did not apply. That inapplicability came through in answers given to survey questions: 'Questions such as "Are you unemployed?", "Are you available for work?", "Are you

\footnotetext{
${ }^{72}$ ILO, Report of the Director-General (1969), pp. 55-6, 83-4, 131.

${ }^{73}$ Protests erupting in Europe in 1968 were an additional influence on this decision. In announcing the WEP, Morse recognized a 'growing unrest among young people in many countries', which took aim at 'the form of society we have been trying to build'. See ILO, Report of the Director-General (1969), p. 102. Critiques of full employment as an inadequate goal for a free society appeared in the pages of the ILR in the 1970s and 1980s. See, for example, David Macarov, 'Planning for a probability: the almost-workless world', $I L R, 124,6,1985$, pp. 629-42.

${ }^{74}$ ILOA, file WEP-3, jacket 1, 'Some data requirements of the WEP', 16 February 1969, p. 1.

${ }^{75}$ Ibid., p. 10.

${ }^{76} \mathrm{Ibid}$.

${ }^{77}$ Ibid., p. 7 , n. 1 .

${ }^{78}$ Ibid., pp. 9-10.
} 
seeking work?" may mean little to a precariously self-employed hawker or peddler in a town, and even less to a peasant leading the only kind of life he knows with no experience that would enable him to visualise anything different. ${ }^{, 79}$ In the absence of relevant social practices, the distinctions on which such judgements are based were simply missing from people's vocabularies. Efforts to force those distinctions into existence resulted in 'pseudo-quantification'. ${ }^{80}$

These reflections pushed ILO economists to see the concepts they were using in a new historical light. In the published version of the working party's reflections, Franklin described the slow emergence of the social conditions that had made it possible to generate standardized categories of employment and unemployment in the West. ${ }^{81}$ He noted that such standardization depended on the support of government policies, such as unemployment insurance, which made it possible for workers without work to remain visibly unemployed, rather than disappearing into precarious self-employment. Developmentalists had expected the social conditions that prevailed in the West to quickly come to prevail in the 'developing world', as the latter industrialized. Those conditions did come to apply in the so-called 'modern' sector of the economy, where wage-labour was the norm, and where state regulations disallowed the casual hiring and firing workers. But the same was not true across the economy as a whole. This problem remained a curiosity as long as the sector to which standard labour-force categories could not be applied was thought to be shrinking. Now, however, that sector was growing rapidly. ${ }^{82}$

Under these conditions, ILO statisticians began to look for alternative measures. They turned at first to Myrdal's proposal in Asian drama. Like the ILO, Myrdal argued that economists should abandon the notion that underemployment was an objective feature of LDC economies (Myrdal focused here on the notion of zero-marginal-productivity workers). ${ }^{83}$ Instead, he argued that economists should seek to apply their own, arbitrarily derived standard, based on what he called 'labour underutilization'. Various approaches to measuring labour underutilization were proposed in the early 1970s, but none was widely adopted. ${ }^{84}$ Then, in 1971, a new concept, 'employment in the informal sector', suggested a way out of this statistical quagmire.

\section{The origins of the concept of 'informal-sector' employment}

The informal sector was the first and only 'completely new topic' discussed by the ICLS in the second half of the twentieth century. ${ }^{85}$ Institutional histories of this term relate it to the passing away of the traditional/modern distinction: over time, it became clear that many activities undertaken in the so-called traditional sector were inherently modern, such as car repair, or were now being carried out in a more modern way, such as beer-brewing. ${ }^{86}$ 'Informal sector' offered a more 'neutral' manner of describing these activities. ${ }^{87}$ While certainly correct, this historical account fails to place the ILO's interest in this term in its proper context: that is, the crisis of its efforts to construct a globally operational measure of unemployment. The ILO abandoned that project in the late 1960s, when ILO economists discovered the existence of an economic sector that was obscure to labour-force statistics, since it was not organized primarily around wage

\footnotetext{
${ }^{79}$ Ibid., p. 9.

${ }^{80}$ Ibid., p. 8 .

${ }^{81}$ N. N. Franklin, 'Employment and unemployment: views and policies, 1919-1969', ILR, 99, 3, 1969, pp. $293-314$.

${ }^{82}$ ILOA, 'Some data requirements', p. 11.

${ }^{83}$ See Mydral, Asian drama, ch. 21 and appendix 16.

${ }^{84}$ See A. D. Smith, Concepts of labour force underutilisation, Geneva: ILO, 1971, pp. 32-66. This text still includes references to 'visible' and 'invisible' forms of underemployment. In spite of its growing unpopularity, the term 'invisible underemployment' was not officially abandoned until a decade later, when prefixes were dropped and underemployment took on its present-day meaning, which refers exclusively to involuntary part-time work. See ILO, Statistics of labour force, employment, unemployment, and underemployment, Geneva: ILO, 1982, p. 47.

${ }^{85}$ Fifteenth ICLS, Report of the conference, Geneva: ILO, 1993, p. 31.

${ }^{86} \mathrm{ILO}$, Kenya report, p. 503; Bangasser, 'ILO', p. 11.

${ }^{87}$ S. V. Sethuraman, 'The urban informal sector: concept, measurement and policy', ILR, 114, 1, 1976, p. 72.
} 
relations. In the ensuing crisis, the originators of 'informality' proposed that it was worthwhile to measure the size of the statistically obscure sector, instead of underemployment in that sector, as a way of overcoming both failures of statistical conceptualization and policy impasses.

The term 'informal sector' first appeared in the ILO country mission reports published in conjunction with IDS economists in the early years of the WEP. By this time, David Morse had been replaced as head of the ILO by Wilfred Jenks, who served a brief term from 1970 to 1973. The reports made under Jenks's tenure are remembered less for the employment policies that they advocated than for the perspective on informality that they advanced. ${ }^{88}$ However, the term 'informal sector' did not actually appear until the third volume in this series, on Kenya. The first two volumes, studies of Colombia and Sri Lanka undertaken in 1970 and 1971, were overseen by Dudley Seers, who still used the older language of disguised unemployment. ${ }^{89}$

Then, in 1971, the anthropologist Keith Hart arrived at the IDS, where he gave a presentation on what he called 'informal economic activities' in the Ghanaian economy. ${ }^{90} \mathrm{He}$ argued that these activities should be encouraged, rather than suppressed, in the course of development. This idea must have seemed like a revelation to researchers at the IDS. ${ }^{91}$ The concept of informality fit easily into the developmental framework that both IDS and ILO economists had been nurturing over the preceding decade. They had argued that economic growth failed to generate adequate employment growth because it was refracted through the prisms of skewed demand compositions and absurd technological incentives. The ILO had been encouraging states to promote the use of labour-using rather than labour-saving techniques to meet the needs of the broad masses of the population, rather than those of a tiny elite. Informal-sector activities met both of these criteria.

The 'informal sector' concept was immediately taken up by Hans Singer and Richard Jolly, for use in the ILO's Kenya report, before Hart even had a chance to publish his ideas. This uptake was an example of a broader trend. Developmental economists were turning to the work of anthropologists and sociologists at a time when their own field was in an impasse. In the Kenya report, Singer and Jolly explicitly distanced themselves from the underemployment framework. ${ }^{92}$ They argued that, in theorizing employment insufficiency, economists had focused on the wrong representative figures: 'the street hawkers, the shoeshine boys, and other groups "underemployed" on the streets of the big towns'. ${ }^{93}$ In reality, Signer and Jolly contended, the informal sector consisted of urban 'enterprises and individuals' performing a wide range of economic activities. ${ }^{94}$ Most of these were actually 'economically efficient and profit making. ${ }^{95}$ The Kenya report went on to argue that the main problem that the small-scale sector faced was that much of what it produced was illegal. The fact that informal enterprises existed 'largely outside of the system of government benefits and regulations' was thus taken to be their key characteristic. ${ }^{96}$ The name 'informal sector' was chosen to suggest that, if impediments to the legalization of small-scale enterprises were lifted, conditions in this sector would improve dramatically. ${ }^{97}$

\footnotetext{
${ }^{88}$ See Eric Thorbecke, 'The employment problem: a critical evaluation of four ILO comprehensive country reports', ILR, 107, 5, 1973, pp. 393-423.

${ }^{89}$ ILO, Towards full employment: a programme for Colombia, Geneva: ILO, 1970, pp. 16-19; ILO, Matching employment opportunities and expectations: a programme of action for Ceylon, Geneva: ILO, 1971.

${ }^{90}$ Subsequently published as Hart, 'Informal income', in 1973.

${ }^{91}$ The moment is noted in IDS, Fifth Annual Report, Sussex: IDS, 1972, p. 29.

${ }^{92}$ ILO, Kenya report, p. 3.

${ }^{93}$ Ibid., p. 5.

${ }^{94}$ Ibid., p. 504.

${ }^{95}$ Ibid., p. 5.

${ }^{96}$ Ibid., p. 504 .

${ }^{97}$ Ibid.
} 
Could the further expansion of the informal sector really solve LDCs' employment problems? It is no coincidence that this report was produced in 1972, a year before the first oil crisis, when the Kenyan economy was still growing rapidly. Rapid growth provided a source of rising demand for goods and services, including those produced by small-scale enterprises. Yet, even in this pre-crisis context, the Kenya report was not wholly optimistic: its authors feared that, in the absence of broader policy changes aimed at sharing out the benefits of economic growth across the population, informal-sector expansion would be not 'evolutionary' but rather 'involutionary' (here, Singer and Jolly deployed a term devised by another anthropologist, Clifford Geertz, in his 1963 study of Javanese agriculture). ${ }^{98}$ Many of the arguments that Singer and Jolly made foreshadowed neoliberal talking points around development, except in this respect: for them, promotion of the informal sector had to fit into a framework aimed at greater equality.

\section{From informal work to 'basic needs'}

In 1973, Francis Bachelard became Director-General of the ILO, overseeing an era in which the term 'informal sector' achieved ever greater prominence within international development discourses. This concept was not without its critics, even in its earliest years. ${ }^{99}$ Nevertheless, it continued to gain adherents, since it coincided with trends in development thinking. In the early 1970s, criticisms of the Keynesian developmental model began to give rise to a new framework. As it turned out, employment insufficiency was only one of a number of issues that had not been resolved by ongoing economic growth. In 1974, a UN housing survey revealed that a large portion of the LDC population lived in slums and squatter settlements, and lacked access to clean water and toilets. ${ }^{100}$ Additional issues had emerged around education and healthcare. Development was failing to deliver these essential goods.

To address these issues, the ILO announced plans for a global employment conference, the WEC, following on the success of its WEP, to be held in 1976. Under the direction of Louis Emmerij, the WEP also introduced a new 'basic needs' perspective to be discussed at the conference. ${ }^{101}$ Previously, the ILO had argued that employment needed to be targeted directly, rather than indirectly by raising economic growth rates. The basic needs perspective extended this principle to a wider range of deprivations: they, too, needed their own direct targets.

Samuel Moyn has recently zeroed in on the ILO's basic needs proposal as marking a shift in wider normative frameworks, from a broader principle of equality to a narrower one of sufficiency. ${ }^{102}$ The latter focused on making sure that the poor had enough to eat; meanwhile, economic inequality was allowed to rise sky high. When it was integrated into the World Bank's justifications for neoliberal structural adjustment in the 1980s, basic needs certainly had this character. However, in its original conception, the notion of basic needs did not divide sufficiency from equality. On the contrary, equality was initially an integral part of this project. ${ }^{103}$

${ }^{98}$ Ibid., p. 505 (see also p. 94, n. 2). See Clifford Geertz, Agricultural involution: the process of ecological change in Indonesia, Berkeley, CA: University of California Press, 1963.

${ }^{99}$ See Colin Leys, 'Interpreting African underdevelopment: reflections on the ILO report on employment, incomes and equality in Kenya', African Affairs, 72, 289, 1973, pp. 419-29; Jan Breman, 'A dualistic labour system? A critique of the "informal sector" concept, I: the informal sector', Economic and Political Weekly, 11, 48, 1976, pp. 1870-6.

${ }^{100}$ Quoted in S. V. Sethuraman, 'Introduction', in S. V. Sethuraman, ed., The urban informal sector in developing countries: employment, poverty and environment, Geneva: ILO, 1981, p. 5.

${ }^{101} \mathrm{ILO}$, Employment, growth and basic needs: a one-world problem, Geneva: ILO, 1977 (henceforth Basic needs).

${ }^{102}$ Samuel Moyn, Not enough: human rights in an unequal world, Cambridge, MA: Harvard Belknap Press, 2018, pp. 11945.

${ }^{103}$ In a retrospective interview, Emmerij explained that, according to ILO thinking at the time, it was 'unrealistic' to try to meet basic needs by way of economic growth alone; changes in 'income distribution' were therefore seen as essential to meeting 'basic needs targets'. See 'Louis Emmerij, interviewed by Ashwani Saith', Development and Change, 36, 6, 2005, p. 1169. 
In 1974, even the World Bank was collaborating with IDS economists around this issue: they collectively produced a volume titled Redistribution with growth. ${ }^{104}$ The year that that lauded report came out was also the year that the NIEO proposal was passed at the UN. In fact, the WEC was originally about the NIEO, before its title was altered to refer to basic needs. ${ }^{105}$

Meanwhile, in its Basic needs report, the ILO radicalized its own positions around inequality. The report backed demands for the redistribution of manufacturing export capacity around the world, but not under the control of multinational corporations. ${ }^{106}$ The report also called more stridently than before for a redistribution of land holdings. ILO officials no longer saw land reform merely as a technical means of reducing demand-compositional skews. They now admitted that they had been wrong to see the state as an 'autonomous' entity, 'which pursues a generalised national interest as articulated by its technicians'; in reality, state action is limited by the interest of 'upper-income groups' who are able to 'exert sustained pressure' on government officials. ${ }^{107}$ Agrarian reform was thus necessary to redistribute political power. ${ }^{108}$

However, by the time that the WEC actually met, various tendencies suggested that the conference report's promises would go unfulfilled. In 1973, full employment came to an end across the developed countries, as both they and non-oil-producing developing countries began to suffer from a sextupling of oil prices. ${ }^{109}$ At the WEC itself, the ILO's basic needs proposal received mixed reviews. Employers' representatives argued in favour of a continued focus on economic growth, at a time when growth was flagging. Given this same context, some government representatives worried that, via the basic needs perspective, LDCs were implicitly being asked to accept long delays on the promises of development. ${ }^{110}$ Then, one year after the WEC met, the United States defunded the ILO, following through on a decision it had made in 1975. The agency lost one-quarter of its operating budget. ${ }^{11}$

By the time that the US restored funding in 1980, global economic conditions had radically shifted. The period from the mid 1960s to the late 1970s had marked an opening with regard to criticism of the economic growth model, which was associated at that time with Keynesianism. That opening now closed. The 'economic growth paradigm', which Morse and others had attacked as inadequate, was restored to its throne. ${ }^{112}$ Crucially, however, economic growth was now dissociated from what had been understood to be one of its primary purposes: full employment was abandoned as a policy objective, but not in the way that critics of this policy had hoped in the 1960s and 1970s. ${ }^{113}$ Critics at the ILO believed that they were aiming at a society of growing leisure. ${ }^{114}$ What they got instead was a world of harried activity.

\footnotetext{
${ }^{104}$ Hollis Chenery, et al., Redistribution with growth: policies to improve income distribution in developing countries in the context of economic growth, London: Oxford University Press, 1974.

${ }^{105}$ The original draft of this document was first released in August 1975; it focused on shifts in the international division of labour. As late as July 1975, conference circulars made no reference to basic needs. See ILOA, file 1001-02, jacket 3, ILO, 'Information paper', July 1975.

${ }^{106}$ ILO, Basic needs, pp. 10, 103, 109. See also ILO, 'Information paper', p. 5.

${ }^{107}$ ILO, Basic needs, pp. 64-5.

${ }^{108}$ Following the WEC, the ILO launched a research programme on 'mass participation and basic needs'. See ILOA, file WEP-2-32-05. Papers from this programme were published in Franklyn Lisk, ed., Popular participation in planning for basic needs: concepts, methods, and practices, Aldershot: Avebury, 1985.

${ }^{109}$ ILO, Basic needs, pp. 26-7.

${ }^{110}$ Louis Emmerij and Dharam Ghai, 'The World Employment Conference: a preliminary assessment', ILR, 114, 3, 1976, pp. 304-5. See also Rodgers, et al., ILO, p. 194.

${ }^{111}$ See Walter Galenson, The International Labor Organization: mirroring the U.N.'s problems, Washington, DC: Heritage Foundation, 1982. Galenson had advised the ILO on the WEP in 1968.

${ }^{112}$ See Matthias Schmelzer, The hegemony of growth: the OECD and the making of the economic growth paradigm, Cambridge: Cambridge University Press, 2016. For a pre-restoration account, see H. W. Arndt, The rise and fall of economic growth, Chicago, IL: University of Chicago Press, 1978.

${ }^{113}$ Wouter van Ginneken, 'Full employment in OECD countries: why not?', ILR, 125, 1, 1986, pp. 19-37; Ajit Singh, 'Institutional requirements for full employment in advanced economies', ILR, 134, 4/5, 1995, pp. 471-95.

${ }^{114}$ See Jean Mouly, 'Employment: a concept in need of renovation', ILR, 116, 1, 1977, p. 3.
} 


\section{Redefining informality in an era of structural adjustment}

All around the globe, in the course of the 1980s, labour protection measures were rescinded and labour markets were deregulated. Policies were introduced that favoured price stability over high levels of employment. Labour 'flexibility', which critics argued was merely a euphemism for labour insecurity, became the order of the day. ${ }^{115}$ Economists even revived the notion that all unemployment was voluntary, claiming that, if people really needed jobs, they would lower their expectations and take the jobs that were available. ${ }^{116}$ Components of this 'neoliberal' perspective find their origins in the first half of the twentieth century; precursors of the neoliberal critique of developmentalists can be found as early as the 1950s. ${ }^{117}$ But these notions were marginal in discussions of development until the 1980s, when the Third World Debt Crisis ushered in longlasting economic depression in many LDCs, and the era of structural adjustment arrived.

The ILO tried to swim against neoliberalism's rising tide, but weakly. The organization attempted to intervene in the structural adjustment lending process, advocating for the inclusion of employment targets in adjustment. ${ }^{118}$ However, the ILO's star, which had been rising in the 1960s and 1970s, was now falling. A high-level meeting between ILO, IMF, and World Bank officials in 1987 came to nothing. ${ }^{119}$ The ILO even failed to produce its own critique of structural adjustment, as an official policy document or recommendation. The first UN criticism of structural adjustment was produced not by the ILO but by UNICEF, although Richard Jolly, one of the co-authors of the UNICEF report Adjustment with a human face, had also co-authored the Kenya report. ${ }^{120}$

Before the Debt Crisis hit, the ILO had already done an about-face on informality: it began to focus, once again, on the work-spreading rather than job-creating characteristics of the informal sector. In 1981, the ILO official S. V. Sethuraman argued that the 'distinguishing feature' of informal activities was that they emerged 'not so much in response to investment opportunities in the neoclassical sense but out of necessity to create one's own employment'. ${ }^{121} \mathrm{He}$ also criticized the notion that 'a shoe-shine boy, a self-employed vendor selling cigarettes on a street corner', or 'a self-appointed building caretaker' could be described as an 'enterprise'. ${ }^{122}$ Yet Sethuraman did not abandon the informality concept. In the 1980s, measuring rates of informality seemed more important than ever before, as a means of calling governments' attention to the social fallout of adjustment. In the midst of an unfolding economic depression, the ILO set itself the task of tracking the expansion of informality across Africa, Asia, and Latin America. ${ }^{123}$ Levels of informality swelled dramatically. Owing to wage freezes and layoffs, workers who once had formal-sector jobs began to work informally as well. ${ }^{124}$ In this context, ILO analysts began to speak of informal activity as they had once spoken of underemployment: that is, as a kind of make-work undertaken in the absence of access to unemployment insurance. $^{125}$

\footnotetext{
${ }^{115}$ J. M. Servais, 'Flexibility and rigidity in international labour standards', ILR, 125, 2, 1986, pp. 193-208.

${ }^{116}$ See Robert Lucas, 'Unemployment policy', American Economic Review, 68, 2, 1978, pp. 353-7. For a critique of the revival of this concept, see Guy Standing, 'The notion of voluntary unemployment', ILR, 120, 5, 1981, pp. 563-79.

${ }^{117}$ See Toye, Dilemmas of development; Plehwe, 'Origins'.

${ }^{118}$ Peter J. Richards, 'Preserving jobs under economic stabilisation programmes: can there be an employment target?', ILR, $125,4,1986$, pp. 423-34.

${ }^{119} \mathrm{ILO}$, High-level meeting on employment and structural adjustment: report of the meeting, Geneva: ILO, 1988; see also ILO, 'Follow-up of the high-level meeting', Geneva: ILO, 1990.

${ }^{120} \mathrm{G}$. A. Corina, Richard Jolly, and Francis Stewart, eds., Adjustment with a human face, volume 1: protecting the vulnerable and promoting growth, Oxford: Clarendon Press, 1987. See also Rodgers, et al., ILO, p. 197.

${ }^{121}$ Sethuraman, 'Introduction', p. 23.

${ }^{122} \mathrm{Ibid}$.

${ }^{123}$ See for example, Susan Horton, Ravi Kanbur, and Dipak Mazumdar, 'Labour markets in an era of adjustment: evidence from 12 developing countries', ILR, 130, 5/6, 1991, pp. 531-58.

${ }^{124} \mathrm{ILO}$, The informal sector and urban employment, Geneva: ILO, 1990, p. 2.

${ }^{125}$ See, for example, ILO, Report of the Director-General: the dilemma of the informal sector, Geneva: ILO, 1991, p. 9.
} 
The problem was that, in making this discursive move, Sethuraman and his colleagues were technically making a claim about why people ended up in the informal sector. That claim could never be proven simply by adding up the number of workers in that sector. In adopting the informal-sector metric, the ILO had moved from working with a direct measure of work insufficiency to an indirect one. That shift took on greater significance in the 1980s, when the implications of rising informality began to be contested. The main locus of the conversation about the informal sector also shifted at this time from Africa to Latin America. ${ }^{126}$ A wider debate now opened up: international agencies, government planners, and economists were joined not only by anthropologists but also by critical sociologists. Soon business associations, labour unions, and even television personalities entered the conversation with their own agendas. ${ }^{127}$

The ILO thus began to lose control over the meaning of the concept that it had developed. In the mid 1980s, the Peruvian economist Hernando de Soto began to use the informality concept in a manner similar to the Kenya report. Like Singer and Jolly, he argued that 'the legal system' was 'the best explanation' for the existence of the informal sector, lobbying on that basis for reductions in business regulations, which he said served to protect formal enterprises rather than society. ${ }^{128}$ This argument had been made in the Kenya report, too. However, de Soto and his acolytes at the World Bank now mobilized this perspective to promote a radically different approach to development. ${ }^{129}$ The Kenya report had encouraged governments to promote greater equality. The Bank, to borrow Ronald Reagan's famous phrase, praised the 'magic of the market'. 130

At the same time, the ILO found itself in critical dialogue with representatives of the 'underground approach'. ${ }^{131}$ The Cuban-American sociologist Alejandro Portes argued that informality was more like a continuum than a sector; its existence served the interests of larger firms, rather than merely competing with them. Portes provided a better empirical description of informality, as the ILO was eventually forced to concede. ${ }^{132}$ However, the underground school's approach, like that of de Soto, was impossible to operationalize in labour-force surveys. ${ }^{133}$ That remained the ILO's focus: producing a broad measure of informality for use in government reports.

\section{Persistent ambiguities at the heart of the 'informality' concept}

In this era, the ILO continued to distinguish itself from other actors precisely by its focus on operability. Although studies of informality were carried out in Calcutta, Dakar, and Bogotá in 1973, and across many LDCs in the later 1970s and 1980s, efforts to standardize an operational concept of informality did not get under way until 1984, when the ILC employment recommendation of 1964 was amended to include a discussion of informal-sector work. ${ }^{134}$ Expert meetings followed in 1992, producing a report for the 1993 ICLS. The spectre of the ILO's earlier

\footnotetext{
${ }^{126}$ For background, see the essays collected in Cathy A. Rakowski, ed., Contrapunto: the informal sector debate in Latin America, Albany, NY: State University of New York Press, 1994.

${ }^{127}$ Cathy A. Rakowski, 'The informal sector debate, part 2: 1984-1993', in ibid., p. 32.

${ }^{128}$ Hernando de Soto, The other path: the invisible revolution in the Third World, New York: Harper and Row, 1989, p. 185.

${ }^{129}$ Ray Bromley, 'Informality, de Soto style: from concept to policy', in Rakowski, Contrapunto, pp. 131-53; World Bank, World development report: workers in an integrating world, Oxford: Oxford University Press, 1995, pp. 70-9.

${ }^{130}$ Quoted in Jennifer Bair, 'Taking aim at the New International Economic Order', in Mirowski and Plehwe, The road from Mont Pèlerin, p. 355.

${ }^{131}$ Rakowski, 'Informal sector', pp. 36-9. See also the essays in Alejandro Portes, Manuel Castells, and Lauren Benton, eds., The informal economy: studies in advanced and less developed countries, Baltimore, MD: Johns Hopkins University Press, 1989.

${ }^{132}$ International Labour Conference (ILC), Decent work and the informal economy, Geneva: ILO, 2002, p. 4.

${ }^{133}$ Rakowski, 'Informal sector', p. 39.

${ }^{134}$ For a more complete list, see ILO, Urbanisation, informal sector and employment, Geneva: ILO, 1984, pp. 17-18. On revisions to the employment recommendation, see ILO, Report of the Director-General (1991), p. 17.
} 
conceptual crisis around underemployment now began to haunt efforts to standardize the measure of informality.

The problem of operability initially reappeared around the question: how should statisticians decide which enterprises were part of the informal sector? The Kenya report had named seven characteristics of informal enterprises, including 'small scale of operation' in 'competitive markets' with 'ease of entry' and the use of 'labour-intensive' technologies. ${ }^{135}$ But choosing any one of these criteria would result in a different measure. That same report had suggested that the term 'informal sector' was chosen because impediments to legal registration were what ensured the continued existence of a disadvantaged, small-scale sector. However, later studies cast doubt on the notion that non-registration could serve as the basis of a definition. There were many different kinds of registration in LDCs, and many small-scale enterprises succeeded in acquiring recognition from government departments to at least some degree. ${ }^{136}$

Based on these reflections, the experts commissioned by the ILO argued that the informal sector had to be defined in another way. ${ }^{137}$ They defined it, first of all, as including household enterprises that did not hire regular employees. In other words, labour statisticians looked once again to the absence of a wage relation, which made these units obscure in terms of standard statistical categories of employment and unemployment. Household enterprises, the statisticians noted, do not engage in bookkeeping, relying mostly on 'casual employment, kinship or personal and social relations rather than contractual arrangements with formal guarantees'. ${ }^{138}$ These were the same features discussed in the 1969 working party report, at the breaking point of the 'disguised unemployment' concept. As a result of this change in definition, the term 'informal' shifted subtly in meaning: it now no longer referred specifically to a lack of legal recognition, but rather, more broadly, to the absence of explicit contracts and written records of work.

At the same time, the scope of the informal sector was expanded to include 'enterprises of informal employers' that did hire some regular workers. ${ }^{139}$ The latter 'micro-enterprises' were agglomerated to the household sector in order to serve as the 'upper segment of the informal sector in terms of productivity and growth'. ${ }^{140}$ The informal sector had already housed both 'marginal activities' with few growth prospects and small enterprises with a strong 'potential for growth'. ${ }^{141}$ The latter part was now made a little larger, and consequently the 'informal sector' concept was rendered even more ambiguous than before. The ILCS accepted this new definition of informality in 1993, while also expanding the scope of the informal sector to include all nonagricultural workers. This finally provided the ILO with the globally operational measure of employment insufficiency that it had been trying to produce since the early 1950s. ILO officials continued to mobilize this measure to draw governments' attention to unmet social needs, but, by this time, governments had largely abandoned broader efforts to meet those needs.

It was therefore all the more concerning that the meaning of the concept that the ICLS produced was ambiguous and open to widespread contestation. It was undeniable that the statistically obscure sector identified by the term 'informality' contained both workers with insufficient employment and employers with profit-making enterprises. That was precisely why, in the 1960s, the ILO had been trying to peer into this sector, to separate out the underemployed workers, who made up the clear majority, from all the rest. The problems that ILO officials continued to encounter in this regard were not only ones of measurement. A deeper problem was that the nature of the informal sector was to some extent indeterminate. In times of economic

\footnotetext{
${ }^{135} \mathrm{ILO}$, Kenya report, p. 6.

${ }^{136} \mathrm{ILO}$, Measurement of employment in the informal sector: a meeting of experts on labour statistics, Geneva: ILO, 1992, pp.

33-7; ILO, Statistics of employment in the informal sector, pp. 8-9.

${ }^{137}$ See the official resolution, included in Fifteenth ICLS, Report, pp. 51-64.

${ }^{138} \mathrm{Ibid}$., p. 53. See also ILO, Measurement of employment, p. 39.

${ }^{139}$ Fifteenth ICLS, Report, p. 54.

${ }^{140}$ ILO, Measurement of employment, p. 41.

${ }^{141}$ Ibid, p. 52.
} 
prosperity, self-employed workers and their families suddenly seemed to be running profitmaking enterprises; at other times, they continued to engage in the same lines of work, in spite of the fact that they were now barely making ends meet. ${ }^{142}$ As informality came to be measured more regularly by more and more government agencies, these ambiguities came to seem like objective features of the sector itself: its 'heterogeneity' and non-identity with working poverty. ${ }^{143}$ In spite of such ambiguities, the ILO continued to point to informality as a useful measure of employment insufficiency for countries where unemployment insurance was unavailable, and hence where such insufficiency did not tend to take the form of unemployment. But ILO pleas for full employment policies were drowned out by much louder World Bank voices, which continued to focus on that part of the sector consisting of hamstrung entrepreneurs, who would benefit from deregulation.

Then, in 2003, the definition of informality that the ILO had recently standardized entered into its own crisis. The adopted definition turned out to be 'inadequate' or even 'misleading', since it had failed to capture the growth of informal employment relationships within the formal sector itself. ${ }^{144}$ As early as 1993, the ILO expert report on informality had noted that, in many countries, 'atypical' employment had expanded within formal enterprises, including 'clandestine employment, involuntary part-time work, work on short-term contract or no contracts, casual work', and 'labour on call'. ${ }^{145}$ As government regulations were torn up in the 1980s and 1990s, large-scale enterprises found themselves more free to hire and fire workers at will, and discovered that they could reliably access a pool of poorly paid and insecure urban workers to replace many of the highly paid and well-protected workers whom they employed. ${ }^{146}$ The ILO now followed Portes and the underground school in abandoning its dual-sector approach. ${ }^{147} \mathrm{New}$ standards were adopted; a new concept of 'informal employment' was born, which counted informal workers in both the formal and the informal sectors. ${ }^{148}$ According to a recent ILO report, there are more than one billion informal workers in the world today, accounting for half of the global non-farm labour force. ${ }^{149}$ A large but unknowable share of this total consists of underemployed workers.

\section{Conclusion}

As part of a larger post-war project aimed at promoting full employment around the world, ILO officials set out to develop a globally operational measure of unemployment for use in LDCs. They discovered that, as long as work for wages did not already constitute a widely recognized social norm, an accurate measure of unemployment levels in LDCs was impossible to construct. The officials were therefore forced to adopt one inadequately substituting metric after another. Here, what was missing was not only a subjective desire for more or better work, but moreover the real abstractions, or divisions within individuals' lives, that work for wages instantiates: between labour-force participation and non-participation, between waged and unwaged work, between employer and employee, and between levels of labour productivity.

\footnotetext{
${ }^{142}$ For a narrative account of this phenomenon, see Katherine Boo, Behind the beautiful forevers: life, death, and hope in a Mumbai undercity, New York: Random House, 2014.

${ }^{143}$ ILC, Decent work, p. 27.

${ }^{144}$ Ibid., p. 2.

${ }^{145}$ ILO, Statistics of employment in the informal sector, pp. 13-14.

${ }^{146}$ See Jan Breman and Marcel van der Linden, 'Informalizing the economy: the return of the social question at a global level', Development and Change, 45, 5, 2014, pp. 920-40.

${ }^{147}$ Sethuraman, 'Introduction', p. 18; ILC, Decent work, p. 4.

${ }^{148}$ See Ralf Hussmanns, Measuring the informal economy: from employment in the informal sector to informal employment, Geneva: ILO, 2005.

${ }^{149}$ ILO, Women and men in the informal economy: a statistical picture, Geneva: ILO, 2018.
} 
When David Morse launched the WEP in 1969, he could still lament that the LDCs lagged behind the highly developed countries in this regard. However, in the 1970s, LDCs turned out to occupy the leading edge of an incipient global tendency: at a time when the employment norm was failing to institute itself across LDCs, this same norm began to break down in North America and western Europe. In both regions, unemployment rates rose significantly. While one part of the ILO was busy measuring the rise of informal work in poorer countries, another part turned its attention to the rise of 'atypical' employment in wealthy economies. ${ }^{150}$ From this perspective, the development of a notion of informal employment can be seen as one aspect of a broader trend: alternative categories of employment insufficiency have proliferated since the 1970s, in the context of what some scholars have described as the 'demise' or 'deconstruction' of unemployment as a conceptual framework. ${ }^{151}$

The history of that demise can also be told, from another angle, as the history of the global disarticulation of GNP measurement from an orientation towards full employment. This disarticulation had certainly been achieved by the late $1980 \mathrm{~s} .{ }^{152}$ However, it was not solely the aim of that decade's neoliberal turn. In the 1960s and 1970s, the connection between the promotion of economic growth and the eradication of unemployment was called into question from across the political spectrum. Many ideas now associated with the critique of neoliberal policies first gained popularity as critiques of Keynesian policies, including not only an attention to rising informality but also the critique of GNP as a measure of well-being, and the proposal of alternative measures that focused on providing universal access to basic services or basic incomes.

Finally, as the histories of 'disguised unemployment' and 'informal employment' show, labour-market realities are shaped not only by economic trends but also by policy frameworks and methods of data collection, all of which influence one other. If 'unemployment' no longer serves as the primary organizing framework for theorizing and measuring employment insufficiency around the world, that is because a sizeable fraction of the global labour force has found itself caught in liminal spaces between unemployment and full employment, with little hope of leaving those spaces. That is due to three things: first, to the continued entry of large numbers of people into labour markets, particularly in LDCs; second, to a persistently low demand for labour, especially for unskilled, manual, and routine labour; and third, to governments' unwillingness or perhaps inability, in the face of economic challenges, to make full employment with the particular sense that this phrase took on in the course of twentieth century - a major policy priority. ${ }^{153}$

Aaron Benanav is a collegiate assistant professor in the Social Sciences Division and an affiliate faculty member in the Department of History at the University of Chicago.

\footnotetext{
${ }^{150}$ Efrén Cordova, 'From full-time wage employment to atypical employment: a major shift in the evolution of labour relations', ILR, 125, 6, 1986, pp. 641-57. 'Atypical employment' often fits precisely Joan Robinson's original definition of disguised unemployment: that is, the movement of individuals from high-productivity jobs in factories into alternative, lowproductivity jobs. However, the latter were now more typically in shopping malls than on street corners.

${ }^{151}$ William Walters, 'The demise of unemployment?', Politics and Society, 24, 3, 1996, pp. 197-219; Jérôme Gautié, 'De l'invention du chômage à sa déconstruction', Genèses, 46, 2002, pp. 60-76.

${ }^{152} \mathrm{See}$, for example, Robert Lucas, 'On the mechanics of economic development', Journal of Monetary Economics, 22, 1, 1988, pp. 3-42.

${ }^{153}$ See for example ILO, Non-standard employment around the world: understanding challenges, shaping prospects, Geneva: ILO, 2016.
} 